\title{
Male Trouble - Writing about Men in Feminist Times
}

\author{
Rob Doyle
}

Copyright (c) 2018 by Rob Doyle. This text may be archived and redistributed both in electronic form and in hard copy, provided that the author and journal are properly cited and no fee is charged for access.

I have published two books so far, and both have concerned themselves primarily with men: with male trials and male frailties, male violence and male desire.

An interviewer once wondered if, having written my novel Here Are the Young Men, I worried I would be dismissed as a 'retrograde angry-male writer'. I replied that it had never occurred to me to worry about that. In the years I spent writing the novel, I was immersed in the work and largely unaware of, or indifferent to, the ideological currents that had made it a potential source of embarrassment to be male and angry and a writer.

I was born in Ireland in the early nineteen-eighties, when Christianity was still the dominant belief system in the country. I grew up with two brothers, no sisters, and few female friends. I was educated at a single-sex Christian Brothers school. I didn't have anything resembling a girlfriend until my late teens.

All of which is to say: you start by writing about what you know, and males were what I knew best.

In the lead up to the publication of Here Are the Young Men, I did feel mildly anxious that the novel would be dismissed as a misogynistic work. It wasn't that I feared offending anyone - the writing is gleefully and indiscriminately offensive - but that the book would be branded a certain way and as a result no-one would read it. My girlfriend at the time, an established novelist herself, reassured me. Female readers, she predicted, would be interested in the novel's brutal examination of young men in general and their attitudes towards women in particular. Women would value the book, she thought, precisely because it was not an exercise in feminist appeasement, but a complex and honest exploration.

It turned out she was right: many of the readers and reviewers who championed the novel were women. I was heartened by this: while masculinity is a natural theme for me, I never intended to write for an exclusively male readership. If anything, I imagined that men would be all too familiar with the social and sexual excruciations depicted in my fiction, and would have less use for its insights than female readers.

Like the often shattered characters I write about, I have lived out an uneasy relationship with my gender and the expectations it imposes. As a teenager in the nineties, I didn't like men. (The word misandry had not yet become fashionable; I doubt I had ever heard it.) Lad culture was at its peak: magazines like FHM and Loaded promoted a model of masculinity centred around booze, birds, shagging, Ibiza, football, cars and materialism. Contemporary malehood was crass and oppressive - especially to someone like me, who could not have passed for a laddish man even if I tried. My attitude towards the culture around 
me was one of loathing and fear. Like my similarly alienated friends, I took refuge in books, punk, art, music, drugs, and a compensatory sense of intellectual superiority. It covered the cracks, for a while.

Much has changed since the nineties. Lad culture is on the retreat, and few will miss it. Men, however, find themselves confronted with new strains of discontent. A feminist revolution is underway in Ireland, its latest victory the resounding vote in favour of loosening the laws around abortion. Ireland is no longer a male-dominated society, and there will be no going back. While the feminist revolution may ultimately alleviate male misery, in this strange interregnum men find themselves under siege. The savagery of inter-male competition - the unrelenting struggle for dominance that constitutes the life of man amongst men - is compounded by a challenge from a previously subservient gender. In an aggressive and tribal online world, men are newly derided and vilified, (as misogyny meanwhile reveals the absolute pitch of its blackness), the humiliation considered fair game after centuries of patriarchal oppression. You can't make a feminist omelette, it seems, without breaking a few male eggs.

Intrinsically resistant to edicts and ideology, fiction provides a lens for studying the open sores of modern gender relations. Some authors are acutely alert to shifting attitudes and the lacerations they leave - and some rub salt in the wounds. In Michel Houellebecq's punishing turn-of-the-century novel Atomised, a forty-something woman named Christiane post-coitally tells her sexually damaged new lover:

Most guys prefer a blow job, they're not really into fucking, they find it difficult to keep it up. But take some guy's cock in your mouth and he's like a little kid again. I think feminism has hit them harder than they like to admit.

It is into a similar terrain of sexual disarray and anxiety that I instinctively write. My most recently published book, This Is the Ritual, explores the battered psyches of men (and some women) who drift through foreign cities, fail in love and art, are enslaved to sex, and hurtle towards the psychic precipice. Pornography, obsession, violence, the ecstasy of carnal pleasure: such themes are the mirrors in which I make sense of my own drives and anxieties. In a culture that insists we think and speak in binaries - black or white, right or wrong, with us or against us - writing affords an oasis of complexity where one need not play nice, nod along to contemporary pieties, think proper thoughts. All vital fiction is a hotbed of thought crime.

Few could seriously regret the collapse of the old Ireland, or believe that the momentous changes taking place are not ultimately for the better. There are many, though, who fall under the wheels of change, get ground up in its gears. These are the people I tend to write about (and perhaps for). The victors do not interest me as much as those who are spat upon, laughed at, derided - the Shylocks of the world.

While I disliked men in the nineties, now I am inclined to sympathize with them: their struggle has gotten fiercer, their crisis more pronounced. If they are acting tough these days, it is probably because they are frightened. In the novel I have recently finished, the narrator shares my name, has had similar experiences, and travelled to the same places as me. In other words, I have dropped the mask of overt fiction to put on a mask that resembles my own face. While the formal strategies may change, the motivating doubts and questions do not. Beneath them all: what could it mean, to be alive, to be a man? 
Rob Doyle was born in Dublin and holds a first-class honours degree in Philosophy, and an MPhil in Psychoanalysis from Trinity College Dublin. His debut novel, Here Are the Young Men, was published by Bloomsbury in 2014, and was chosen as a book of the year by The Irish Times, The Sunday Times, The Sunday Business Post, and Independent. It was shortlisted in the Best Newcomer category for the Bord Gáis Irish Book Awards, and is one of Hot Press magazine's "20 Greatest Irish Novels since 1916”. Doyle's second book, This Is the Ritual, was published in January 2016 (Bloomsbury / Lilliput). His fiction, essays, and criticism have appeared in The Guardian, The Observer, The Dublin Review, The Irish Times, The Sunday Times, The Sunday Business Post, Stinging Fly, Gorse, Dalkey Archive's Best European Fiction 2016, and elsewhere. Rob has also played the lead role in Hit the North (2016), a feature film directed by Daniel Sayer, and is the editor of the Dalkey Archive's Anthology of Irish Literature, due for publication in 2017. 